Nig. J. Biotech. Vol. 38 (1) : 160-165 (June 2021)

ISSN: 01891731

Available online at

NIGERIAN JOURNAL OF

BIOTECHNOLOGY

http://www.ajol.info/index.php/njb/index

and www.biotechsocietynigeria.org

DOI: https://dx.doi.org/10.4314/njb.v38i1.19

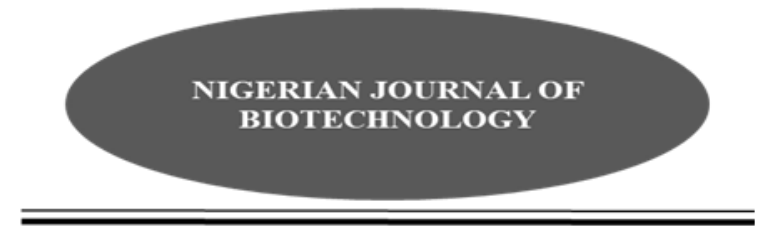

\title{
Isolation and Identification of Phenol-Degrading Bacteria from Oil-Contaminated Sites
}

\author{
${ }^{1}$ Usman Z. M., ${ }^{1}$ Said M. A., ${ }^{2}$ Shehu F.A., ${ }^{3}$ Abdussalam K., ${ }^{4}$ T.M. Abdulrazak., \\ and ${ }^{* 1,2}$ Abdullahi $\mathbf{N}$. \\ ${ }^{1}$ Department of Biological Sciences, College of Natural and Applied Science, Alqalam University \\ Katsina, Katsina State, Nigeria. \\ ${ }^{2}$ Department of Biochemistry, Faculty of Basic Medical Sciences, Bayero University Kano, Kano \\ State, Nigeria. \\ ${ }^{3}$ Chemical Pathology Unit, Bayero University Kano /Aminu Kano Teaching Hospital, Kano State, Nigeria. \\ ${ }^{4}$ Department of Science Laboratory Technology, School of Applied Science Federal Polytechnic Offa, \\ Kwara State, Nigeria.
}

\begin{abstract}
This work is aimed at isolating and identifying phenol-degrading bacteria from oilcontaminated sites. Five soil samples from three auto-mechanic workshops within Katsina metropolis were collected. The samples were analyzed by selective enrichment technique, which resulted in the isolation of four bacterial species. The species were further subjected to the Vitek 2 compact microbiological system analysis. Cupriavidus pauculus, Pontoea spp, Proteus mirabilis 1 and Proteus mirabilis 2 were identified. Result from the present study showed that the bacteria could utilize phenol as their carbon source. Proteus mirabilis 1 and Proteus mirabilis 2 showed lower phenol degradation potential, under similar conditions. Cupriavidus pauculus and Pontoea sp. showed significant increases $(p<0.05)$ in their optical densities. The optical density increment is strongly correlated with increase in colony forming units of the bacteria. This study further showed that the isolates could tolerate high phenol concentrations and may serve as strong putative isolates in bioremediation of phenol-contaminated sites.
\end{abstract}

Keywords: phenol, biodegradation, bioremediation, bacteria, oil-contaminated sites

*Corresponding Author's Email and Phone Number: nabdullahi.bch@buk.edu.ng: 09079461475

\section{Introduction}

The exploration of the environment by man in the quest to survive has generated some negative impact on the ecosystem (Ojuederie and Babalola, 2017). Pollution is one of the major impacts of man's activity which has caused threat to life. Phenol is one of the major pollutants found in oil contaminated sites (Gami et al, 2014). Phenol and its compounds like chlorophenols and nitrophenols, among others, are injurious to humans and other flora and fauna at oil-contaminated sites even at low concentrations. Symptoms including irritation of the skin and eyes, diarrhea and vomiting have been associated with hydrocarbon pollutants. Other significant morbidities like cancers, coronary heart diseases, kidney, and liver failure have been reported in individuals exposed to phenol and other aromatic pollutants (Abubakar and Shukor, 2017). 
Physicochemical and biological methods can be applied in order to remediate the toxic effect of phenols (Riser-Roberts, 2020). Biological methods have been shown to be cost-effective in bioremediation of phenols. This study is aimed at identifying, isolating phenol degrading bacteria from oil contaminated sites and to determine the phenol degrading ability of such bacteria at oil contaminated sites within Katsina Metropolis.

\section{Materials and Methods}

\section{Sample Collection}

Samples were collected in clean polythene bags from contaminated sites. The samples were homogeneously mixed together to form a bulk (Ayandiran and Dahunsi, 2017).

\section{Isolation and identification of Hydrocarbon Utilizing Bacteria}

The total population of the hydrocarbon-utilizing bacteria was obtained by pour plate method on minimal salt medium (MSM) using phenol as the sole source of carbon. The morphological characteristics of the bacterial isolates were identified by Gram staining and biochemical reactions (Udeani et al., 2009). All the isolates were screened for phenol utilization capabilities in mineral salt broth medium (Okpokwasili and Nweke 2006). Vitek 2 compact system (A microbiological analyzer) was used to identify the bacteria (Garcia-Garrote et al, 2000).
Determination of phenol biodegradation of selected bacterial isolates

Isolates that showed good utilization potentials of phenol during the screening test were selected for biodegradation studies. The ability of the bacterial isolates to degrade phenol was confirmed by inoculating each isolate into 250 $\mathrm{mL}$ Erlenmeyer flask containing $100 \mathrm{~mL}$ mineral salt medium. Phenol $(0.6 \%)$ was used to serve as carbon source, while the strains were tested for growth by turbidity formation as described by Mills et al. (1978) with slight modifications. The concentration of phenol was increased to $1 \%$ and the growths of individual organisms were also monitored over 15 days. The $\mathrm{pH}$ of the culture broth was taken at intervals.

\section{Results}

Isolates were screened for phenol utilization capabilities in mineral salt broth medium with phenol $(0.6 \%)$ as carbon source. Four bacterial isolates (Cupriavidus pauculus, Proteus mirabilis 1, Proteus mirabilis 2 and Pantoea Spp) were identified by Gram staining and biochemical reactions (Table $\mathbf{1}$ ). The strains were bacillus specie, among which only Pantoea spp tested positive to oxidase reaction. Pantoea spp did not produce hydrogen sulphide and could not ferment glucose as compared to the other three bacteria isolates (Cupriavidus pauculus, Proteus mirabilis 1 and 2)

Table 1: Identification of the bacteria isolated from the soil sample on mineral salt agar medium

$\begin{array}{lllll}\begin{array}{l}\text { Biochemical } \\ \text { Reaction }\end{array} & \text { Cupriavidus pauculus. } & \begin{array}{l}\text { Proteus } \\ \text { mirabilis. (1) }\end{array} & \begin{array}{l}\text { Proteus mirabilis. } \\ \text { (2) }\end{array} & \text { Pantoea Spp }\end{array}$

(2)

\begin{tabular}{|c|c|c|c|c|}
\hline Gram Reaction & - & - & - & - \\
\hline Morphology & Rod & Rod & Rod & Rod \\
\hline Oxidase & - & - & - & + \\
\hline Indole & + & + & + & - \\
\hline Glucose & $\mathrm{F}$ & $\mathrm{F}$ & $\mathrm{F}$ & NF \\
\hline Lactose & $\mathrm{F}$ & $\mathrm{F}$ & $\mathrm{F}$ & $\mathrm{F}$ \\
\hline Sucrose & $\mathrm{F}$ & $\mathrm{F}$ & $\mathrm{F}$ & $\mathrm{F}$ \\
\hline $\begin{array}{l}\text { Growth in } 5 \% \text { of } \\
\mathrm{NaCl}\end{array}$ & + & + & + & + \\
\hline Hydrogen Sulphide & $P$ & $P$ & $P$ & - \\
\hline
\end{tabular}

Key: $+=$ Positive,$-=$ Negative, $\mathrm{F}=$ Fermented, $\mathrm{NF}=$ No Fermentation, $\mathrm{P}=$ Produced 
The optical density and $\mathrm{pH}$ were taken for the isolates at $30{ }^{\circ} \mathrm{C}$ for 15 days. Cupriavidus pauculus showed a significant $(\mathrm{p}<0.05)$ increase in O.D (1.434 at $600 \mathrm{~nm}$ wavelength) as compared to the Pantoea $s p$ and Proteus mirabilis (1 and 2) strains. The bacteria count (Aerobic Mesophilic Bacterial Count, cfu/mL) was also estimated, the growth of the organisms on phenol is an indication that the strains could possibly utilize phenol as its carbon source (Table 2). The $\mathrm{pH}$ at the optimum OD (1.434) was 7.92. Pantoea spp had the highest $\mathrm{pH}$ (8.10) even though its OD was significantly lower $(p<0.05)$ when compared with Cupriavidus pauculus. Proteus mirabilis (1) had the least $\mathrm{OD}$ and $\mathrm{pH}(0.393$ and 6.71 respectively). The optimum growth of the organisms was observed after $9^{\text {th }}$ day.

Table 2: Optical density and $\mathrm{pH}$ for screening of phenol $(0.6 \%)$ biodegradation of bacteria on minimal salt medium at $30^{\circ} \mathrm{C}$ for 15 days

\begin{tabular}{lccc}
\hline \multicolumn{1}{c}{ Bacterial Isolates } & $\mathbf{p H}\left(\mathbf{l o g}^{\mathbf{1 0}}\right)$ & $\mathbf{0 . D}(\mathbf{6 0 0} \mathbf{~ n m})$ & AMBC $(\mathbf{x 1 0} \mathbf{~} \mathbf{c f u} / \mathbf{m L})$ \\
\hline Pantoea spp & 8.10 & 0.942 & 20.6 \\
Proteus mirabilis (1) & 6.71 & 0.393 & 8.7 \\
Proteus mirabilis (2) & 7.40 & 0.709 & 15.5 \\
Cupriavidus pauculus & 7.92 & 1.434 & 62.4 \\
\hline
\end{tabular}

Key: $\mathrm{AMBC}=$ Aerobic Mesophilic Bacterial Count, $\mathrm{cfu} / \mathrm{mL}=$ colony forming unit per milliliter, $\mathrm{nm}=$ nanometer, O.D = Optical Density (absorbance).

Tolerance of Cupriavidus pauculus in phenol $(1 \%)$ and minimal salt medium was observed for 15 days at $30{ }^{\circ} \mathrm{C}$. The optical density (OD) at the optimum $\mathrm{pH}$ was 0.26 . There is an exponential growth of Cupriavidus pauculus corresponding to the rate of degradation from the $1^{\text {st }}$ day to the $9^{\text {th }}$ day. The $\mathrm{pH}$ of the culture media was continuously measured during the growth. The $\mathrm{pH}$ at the optimum growth was
6.89 (Figure 1). There was a decrease in $\mathrm{pH}$ of the culture when Cupriavidus pauculus was grown in $1 \%$ phenol. A significant decrease in optical density (0.26) was observed when Cupriavidus pauculus was grown in $1 \%$ phenol concentration as compared to $0.6 \%$. The decrease in OD might be due to the increased concentration of phenol.

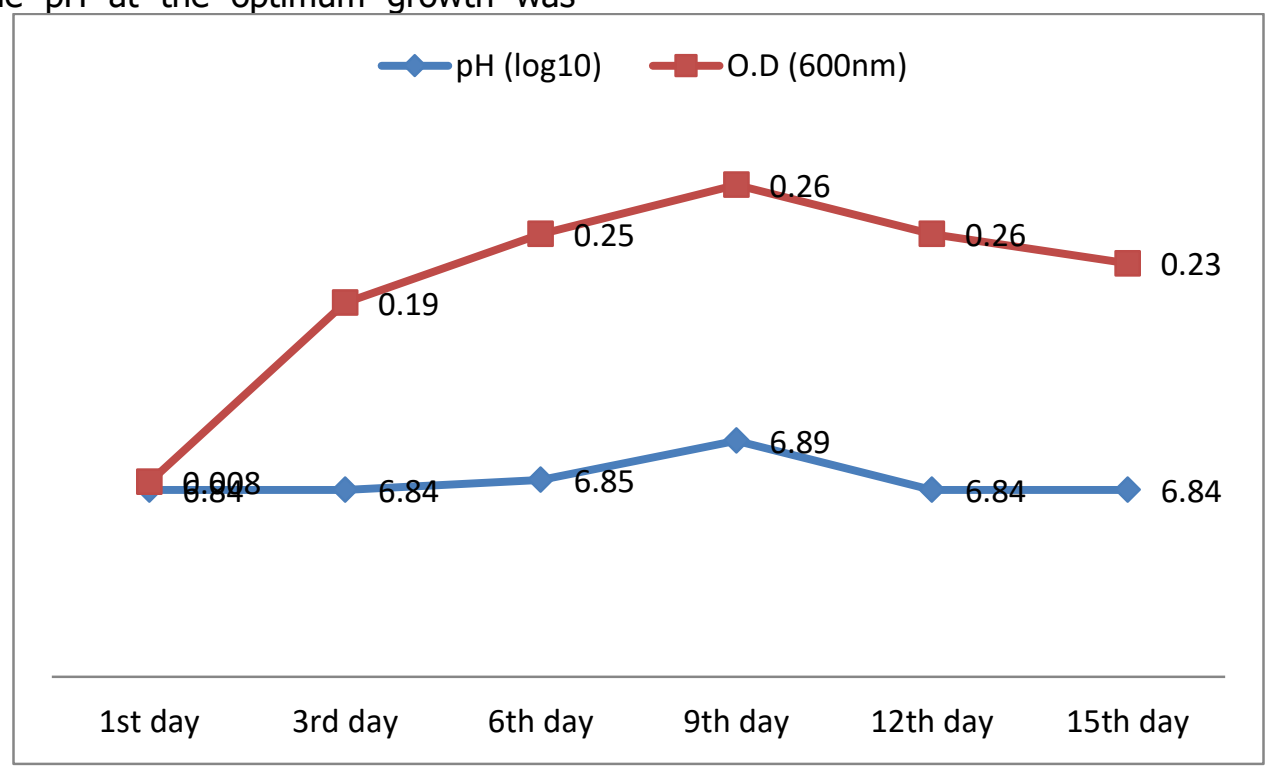

Figure 1: Tolerance of phenol $(0.6 \%)$ with Cupriavidus pauculus on minimal salt medium at $30^{\circ} \mathrm{C}$ for 15 days

The tolerance of Proteus mirabilis (1) in phenol (1\%) and minimal salt medium was observed for
15 days. There was an exponential growth of the microbe corresponding to the rate of 
degradation from the $1^{\text {st }}$ day to the $9^{\text {th }}$ day. The $\mathrm{pH}$ of the culture media was continuously measured during the growth. The $\mathrm{pH}$ at the optimum growth (0.26) was 8.66 (Figure 2). An increase in $\mathrm{pH}$ was observed when compared with Cupriavidus pauculus. A significant decrease $(p<0.05)$ in optical density $(0.26)$ was observed when Proteus mirabilis (1) was grown in $1 \%$ phenol concentration as compared to $0.6 \%$ phenol concentration. The changed in the $\mathrm{pH}$ from 6.71 to 8.66 might have an effect on the growth of Proteus mirabilis (1).

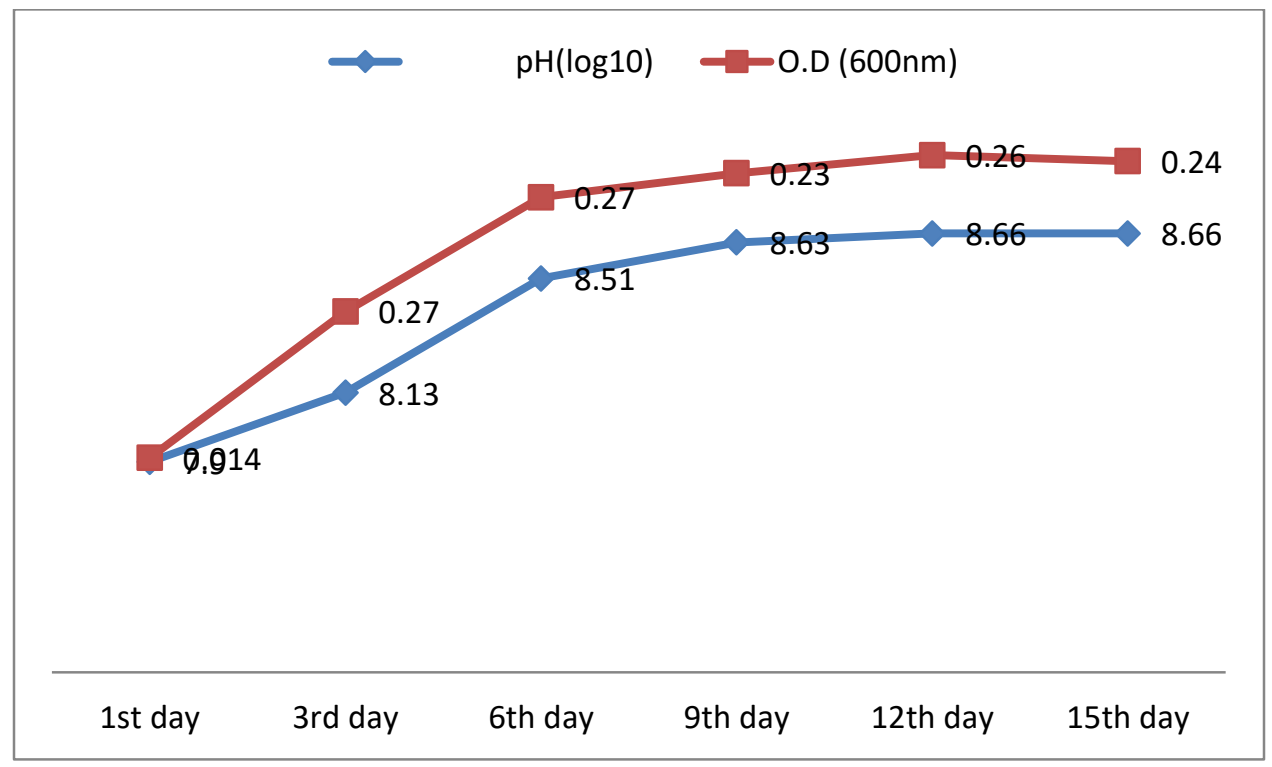

Figure 2: Tolerance of phenol (1\%) with Proteus mirabilis (1) on minimal salt medium at $30^{\circ} \mathrm{C}$ for 15 days.

Proteus mirabilis (2) was also cultured in $1 \%$ of phenol with minimal salt medium for 15 days to observe its tolerance in phenol. There optimum growth was obtained at $0.24 \mathrm{OD}$, at $\mathrm{pH}$ of 7.41 . An exponential growth was also seen of between the $1^{\text {st }}$ and the $9^{\text {th }}$ days (Figure 3 ).
Both proteus species have an optimum growth in alkaline media at $1 \%$ phenol concentration. The slight increase in $\mathrm{pH}$ and a decrease in OD signiy that increase in $\mathrm{pH}$ might have affected the growth of the microbes.

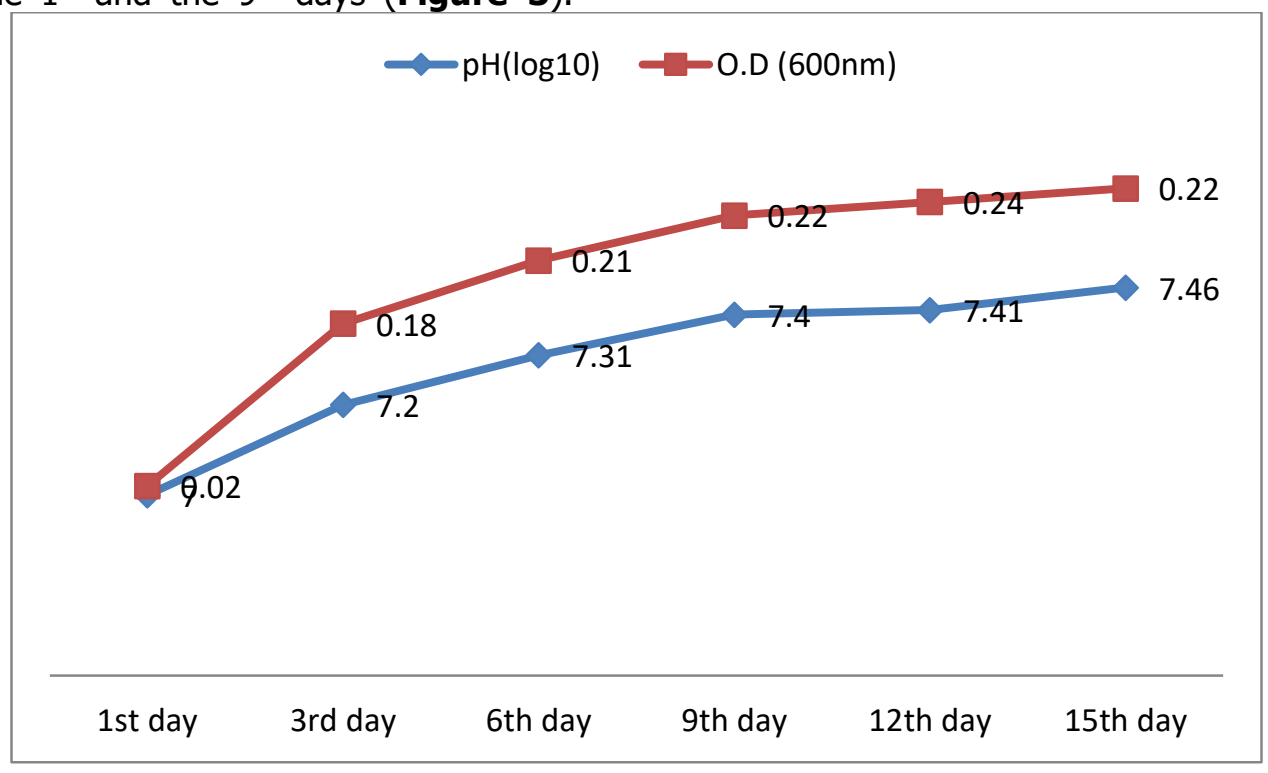


Figure 3: Tolerance of phenol (0.6\%) with Proteus mirabilis (2) on minimal salt medium at $30^{\circ} \mathrm{C}$ for 15 days

Tolerance of Pantoea sp. in phenol (1\%) and minimal salt medium was observed for 15 days at $30^{\circ} \mathrm{C}$. The optical density $\mathrm{OD}$ at optimum $\mathrm{pH}$ was 0.36 , this showed an exponential growth of Pantoea $s p$. corresponding to the rate of degradation from the $1^{\text {st }}$ day to the $9^{\text {th }}$ day. The $\mathrm{pH}$ of the culture media was continuously measured during the growth. The $\mathrm{pH}$ at the optimum growth was 7.93 (Figure 4) and this is a clear indication that Pantoea $s p$. requires an alkaline $\mathrm{pH}$ for the degradation of phenol. There was no significant difference in the $\mathrm{pH}$ when Pantoea $s p$. was grown in $1 \%$ and $0.6 \%$ phenol concentrations.

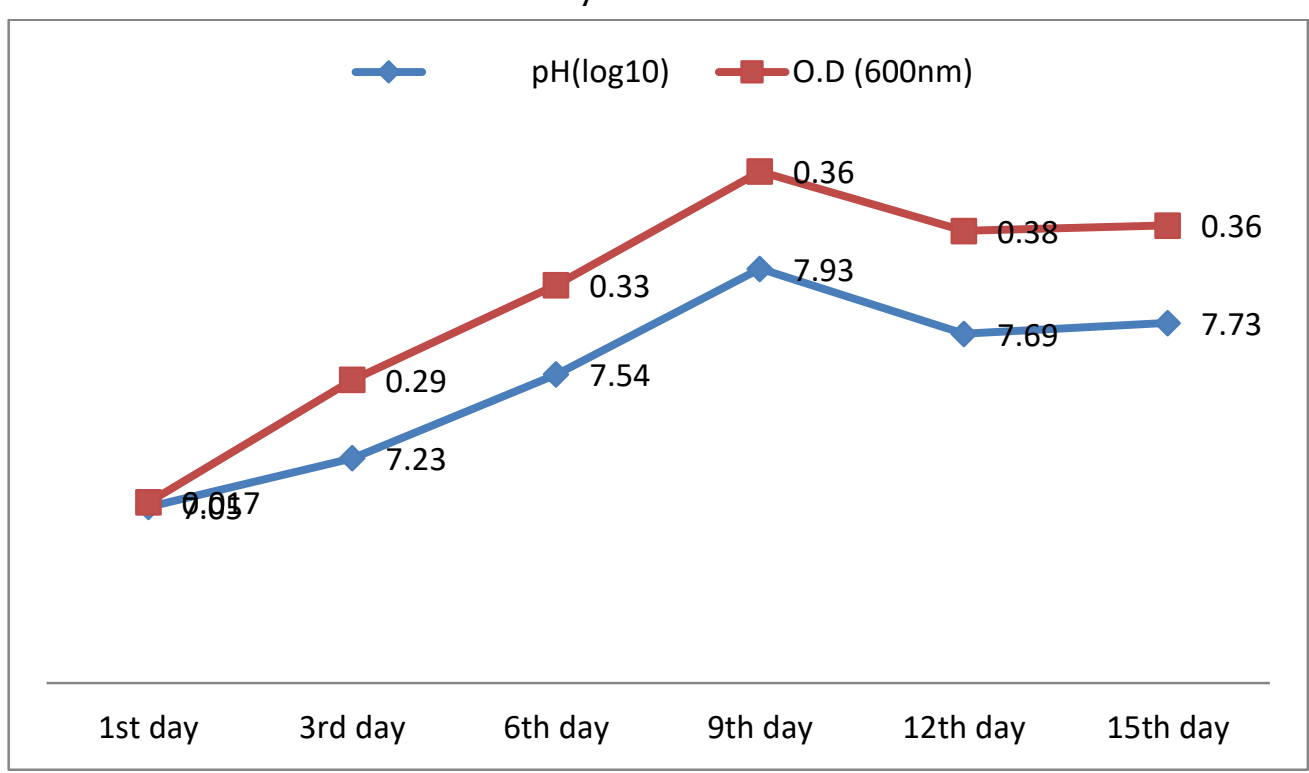

Figure 4: Tolerance of phenol with Pantoea sp. on minimal salt medium at $30^{\circ} \mathrm{C}$ for 15 days

\section{Discussion}

This study was aimed at isolating and identifying phenol-degrading bacteria from oil-contaminated sites in Katsina Metropolis. Four isolates showed biodegrading ability towards phenol. The isolates were identified using biochemical reaction tests (Table 1 ). The isolates were further identified using an automated microbiological system (Vitek 2) as Pantoea spp., Proteus mirabilis (1) and (2) and Cupriavidus pauculus. Preliminary screening indicates that the bacteria were all Gramnegative bacteria belonging to the Bacillus $s p$. Pantoea Spp was the only bacteria that showed negative response to indole and hydrogen sulphide test. Cupriavidus pauculus is well known for its degradability activities and is found in the plant rhizoids. Since microorganisms in the soil especially those associated with plants enhance or stimulate phytoremediation, therefore, it is possible that Cupriavidus pauculus may be implored in phenol rich environment to degrade phenols, thereby improving the plants accessibility to nutrients.

Screening showed the good ability of the bacteria to tolerate phenol as the sole source of carbon and the isolates were able to grow well on phenol when screened for hydrocarbon utilization (Figures 3 to 6 ). The $\mathrm{pH}$ values of each medium containing the isolates showed a significant increment $(p<0.05)$ with increasing number of days of incubation. This signified that the isolated bacteria increased the $\mathrm{pH}$ of the medium to slightly alkaline and that biodegradation of phenol may be best achieved at slightly alkaline $\mathrm{pH}$. The result obtained in this work is similar with the studies conducted by Mbachu et al. (2014) which showed an increase in $\mathrm{pH}$ with bacteria growth. Similarly, this work is in agreement with that of Onuoha et al. (2011) studies, which showed continuous increase in O.D. and number of total viable count with increasing number of days. The exponential growth of the microbe 
corresponding to the rate of degradation clearly indicates that the microbe was able to tolerate such high concentration of phenol and also able to utilize it as its carbon and energy source. The maximum growths for all the tested bacterial isolates were obtained in day 12 . Cupriavidus pauculus showed the highest utilizing potential of phenol having the highest aerobic mesophilic bacterial count of $62.4 \times 10^{8} \mathrm{cfu} / \mathrm{g}$, which is an evidence of utilization of phenol. The least in terms of aerobic mesophilic bacterial count among all the isolates is Proteus mirabilis (1) having the aerobic mesophilic bacterial count of $8.7 \times 10^{8} \mathrm{cfu} / \mathrm{g}$. According to Gomez et al (2013), bacteria isolated from phenol rich contaminated sites could tolerate phenol considering their better proliferation when incubated in phenol rich media. The optical density increment correlates to an increase in cell number. This showed that the bacterial isolates can grow effectively in phenol-rich substrate. The present study demonstrates the phenol biodegradation potentials of these isolates.

\section{References}

Abubakar, A., and Shukor, M. Y. (2017). Phenol removal via cellular immobilization: $A$ review. Bioremediation Science and Technology Research, 5(2), 1-7.

Ayandiran, T. A. and Dahunsi, S. O. (2017). Microbial evaluation and occurrence of antidrug multi-resistant organisms among the indigenous Clarias species in River Oluwa, Nigeria. Journal of King Saud University-Science. 29, 96-105.

Gami, A. A., Shukor, M. Y., Khalil, K. A., Dahalan, F. A., and Ahmad, S. A. (2014). Phenol and its toxicity, Journal of Environmental Microbiology and Toxicology. 2 (1), 11-24.

Garcia-Garrote, F., Cercenado, E. and Bouza, E (2000). Evaluation of a new system, VITEK 2, for identification and antimicrobial susceptibility testing of enterococci. Journal of Clinical. Microbiology. 38, 2108-2111.

Gomez, E. F., and Michel, Jr. F. C. (2013). Biodegradability of conventional and bio-based plastic and natural fiber composites during composting, anaerobic digestion and long-term soil incubation. polymer degradation and stability. Journal of Clinical Microbiology. 98 (12), 2583-2591.

Mbachu, A. E., Onochie, C. C., Agu, K. C., Okafor, O. I. and Awah, N. S. (2014). Hydrocarbon degrading potentials of indigenous bacteria isolated from auto-mechanic workshops at Mgbuka-Nkpor. Nigeria. Journal of Global Biosciences. 3 (1), 321-326.

Mills, A. L., Breuil, C. and Colwell, R. R. (1978). Enumeration of petroleum-degrading marine and estuarine microorganisms by the most probable number method. Canadian Journal of. Microbiology. 24, 552-557.

Ojuederie, O. B., and Babalola, O. O. (2017). Microbial and plant-assisted bioremediation of heavy metal polluted environments: a review. International Journal of Environmental Research and Public Health. 14(12), 1504.

Okpokwasili, G. C. and Nweke C.O. (2006). Microbial growth and substrate utilization kinetics. African Journal of Biotechnology. 5 (4), 305-317.

Onuoha, G., Youssef, C. B., and WaissmanVilanova, J. (2011). Two-step modeling of the biodegradation of phenol by an acclimated activated sludge. Chemical Engineering Journal, $117(3)$, 245-252.

Riser-Roberts, E. (2020). Remediation of petroleum contaminated soils: biological, physical, and chemical processes. CRC press.

Udeani T. K. C., Obroh A. A., Okwuosa C. N., Achukwu P. U. and Azubike N. (2009). Isolation of bacteria from mechanic workshops' soil environment contaminated with used engine oil. African Journal of Biotechnology. Vol. 8 (22), pp. 6301-6303. 